\title{
Reposisi Perempuan Islam dalam Bingkai Historiografi
}

\author{
Nur Ikhlas \\ STAIN Sultan Abdurrahman Kepri \\ nurikhlas02@gmail.com
}

\begin{abstract}
This research describes women, which explains in full about the historical aspects of women with historiography and in the view of Islam. The historical proves that women have not involved much since the beginning of history until now, but in recent years gender has been one of the most down to earth discussions. However, this paper will discuss gender issues. This paper will reveal how women in historiography and in the history of Islamic history. The history of women is quite a complicated matter, given the very insignificant history of women accepted in history. Historians say "women hidden in history" are considered women considered not important in the course of history. It is important that in terms of the journey of women it is quite important and very important from the historical development both in terms of historiography and in the course of Islam. Writing this paper collects data from various research books and journals about women and other data relating to discussion in this paper.
\end{abstract}

Keywords: Women, History, Islam

\begin{abstract}
ABSTRAK
Penelitian ini menguraikan tentang perempuan, yang dijelaskan dengan rincian dari segi sejarah perempuan secara historiografi dan dalam pandangan Islam. Sejarah membuktikan bahwa perempuan tidak banyak terlibat sejak periode awal sejarah itu ada hingga sekang, namun pada beberapa tahun terakbir gender salah satu pembahasan yang cukup membumi. Akan tetapi pada makalah ini tiak akan dibahas masalah gender. Makalah ini akan mengungkap bagaimana keterlibatan perempuan dalam historiografi dan dalam perjalanan sejarah Islam. Sejarah perempuan merupakan suatu hal yang cukup rumit, mengingat penulisan sejarah perempuan sangat langka babkan tidak tercatat dalam sejarah. Sejarawan mengatakan babwa "wanita tersembunyi dalam sejarab" dikarenakan perempuan dianggap tidak terlalu penting dalam perjalanan sejarah. Sebenarnya jika ditinjau dari perjalanan nya perempuan cukup penting dan sangat berpengaruh dari perkembangan sejarah baik itu ditinjau dari historiografi dan dalam perjalanan Islam. Penulisan makalab ini megumpulkan data-data dari berbagai penelitian bukubuku dan jurnal tentang perempuan serta data-data lainnya yang berkaitan dengan pembahasan makalah.
\end{abstract}

Kata kunci: Perempuan, Sejarah, Islam 


\section{PENDAHULUAN}

Menulis Sejarah, terutama sejarah perempuan bukan sekedar kegiatan intelektual atau akademis karena kegiatan penulisan sejarah tidak terlepas dari pengaruh politik. Mengenai asal-usul, kedaulatan wilayah, pemegang kekuasaan, penghianat dan penjahat juga hal-hal lain yang berkaitan dengan sejarah sudah menjadi pokok pembahasan dan menimbulkan perdebatan panjang dalam sejarah.

Sejarah perempuan sangat erat hubungannya dengan gender, yang beberapa tahun terakhir ini marak dibahas di Indonesia. Tidak dapat dipungkiri bahwa ketika orang berbicara tentang gender, maka konotasinya pada wanita. Hal ini disinyalir oleh Joan Wallace Scott dalam arti yang sederhana gender adalah synonim untuk wanita. (Scott, Gender and the Politics of History, 1988, hal. 31) Istilah gender adalah hasil dari kontruksi masyarakat bukan kodrat yang sebenarnya.

Melihat perkembangan historiografi di dunia, juga di Indonesia dapat dikatakan bahwa sejarah adalah milik kaum laki-laki. (Kuntowijoyo, 1994, hal. 99) Selain karena kurangnya peminatan sejarah dari kalangan perempuan itu sendiri, juga karena para penulis sejarah lebih tertarik kepada penulisan yang nyata dibidang politik dan ekonomi serta besarnya peminatan di bidang keilmuan lainnya. Penulisan sejarah yang berpusat kepada laki-laki ini disebut juga dengan androsentris, bambang Purwanto mengatakan bahwa "baik secara sadar atau tidak, realitas historis perempuan telah diabaikan sebagai proses sejarah Indonesia". (Purwanto, 2006, hal. 35)

Mereka melihat bahwa gerakan perempuan terbatas dibanding lakilaki, bukan sebuah kenistaan lagi bahwa penulisan sejarah perempuan sudah sangat terkebelakang, apa lagi di Indonesia. Alhasil, eksistensi penulisan sejarah di dunia ini terkesan hanya dihuni oleh laki-laki.

Ann D. Gordon dan kawan-kawan dalam artikelnya yang berjudul "The problem of Women History" (Carroll, hal. 75) dikatakan bahwa hal yang 
signifikan dalam wanita adalah timelessness tak dibatasi oleh waktu, perempuan lebih patut dirumah, mengandung dan memelihara anak. Hal ini tentunya gambaran yang tidak adil tentang perempuan.

Secara ideologis, pembatasan ruang gerak terhadap perempuan, juga dipicu oleh kekhawatiran kaum laki-laki timbulnya pemikiran bahwa perempuan disinyalir akan menyaingi laki-laki jika seandainya dia berkuasa diruang publik. Karena perempuan sangat berpengaruh pada pertumbuhan kehidupan masyarakat. (Kowani, 1984, hal. 34) Apalagi perempuan dikalangan bangsawan dianggap sebagai panutan bagi rakyatnya.

\section{PEREMPUAN DALAM HISTORIOGRAFI}

Dalam perkembangan penulisan historiografi $1^{1}$ sulit ditemukan penulis yang khusus menulis sejarah perempuan. ${ }^{2}$ (S. Handayani, 2004, hal. 6) Walaupun ada hanya beberapa tulisan seperti menulis tentang biografi tokoh perempuan, namun pada umumnya penulisan tersebut bukan dalam ilmu sejarah akan tetapi lebih kepada keilmuan sosial. Corak penulisan sejarah sering juga disebut bersifat androsentris hal ini menjadikan perempuan hanya sebagai figuran. Selain itu, sejarah masa lalu identik hanya dengan orangorang besar yang sudah melakukan hal yang berarti dalam perjalan pergerakan dari masa ke masa, dan orang-orang kecil tidak akan pernah termaktub dalam sejarah. Padahal sebenarnya jika kita perhatikan lagi orang kecil juga berpengaruh dan layak tercatat dalam sejarah.

${ }^{1}$ Merupakan salah satu bagian dari tahapan dalam proses merekonstruksi sejarah. Tahapan dimulai dari pencarian sumber, terdiri dari sumber primer dan sekunder kemudian diadakan kritik yang terdiri dari kritik intern dan ekstern bertujuan untuk menentukan kevaliditasan sebuah sumber data. Lalu melakukan pendeskripsian fakta-fakta dalam bentuk narasi.

2 Istilah "Perempuan" diyakini berasal dari bahasa sansekerta, yang memiliki kata dasar "wa" yang berarti nafsu, sehingga istilah "perempuan" mempunyai arti yang "dinafsuhi" atau objek seks. Dalam bahasa Jawa (Jawa Dorsok), istilah "Perempuan" berarti "wanita ditata" yaitu "berani ditata". Pemahaman orang jawa ini secara simbolik mengubah pemahaman terhadap istilah "perempuan" yang sebelumnya hanya dianggap sebagai objek, berubah menjadi subjek. 
Berkaitan dengan perubahan-perubahan sejarah dan orientasiorientasi multidisiplin feminisme, memanglah problematik untuk mendefenisikan suatu konsep. Akan tetapi, seseorang dapat mendefenisikan feminisme dalam terminologi sejarah, perkembangan dan fragmentasinya ke dalam banyak sekali bentuk yang berbeda. Para peneliti feminisme Barat secara umum mempunyai keyakinan bahwa pria mendominasi sebuah masyarakat dalam bidang-bidang tertentu, perempuan akan menjadi kelompok yang tertindas dan pasif. (S.Duval, 1998, hal. 46) Feminisme Barat merupakan keberlanjutan dari sebuah proses sejarah, seseorang dapat berpandangan bahwa basis feminisme Barat merupakan produk dominasi eksklusivitas gender oleh Gereja dan diskriminasi yang vulgar antara pria dan perempuan serta pengingkaran terhadap perempuan dalam konteks sosial Barat. Semuanya terjadi pada suatu periode ketika pria dari kelas tertentu memerintah serat mendominasi kekuasaan secara eksklusif dan kepemilikan dalam semua aspek kehidupan sosial ekonomi.

Sejarah dalam arti gerak maju secara berkelanjutan sebagaimana historiografi, mendasar pada obyektif aktivitas perempuan menjadi hilang dalam penulisan. Hilangnya perempuan ketika masuk ke dalam waktu obyektif sejarah salah satu faktor nya dikarenakan perempuan mempunyai waktu natural yang geraknya berputar. Waktu natural perempuan berbeda dengan waktu sejarah.

Maka dari itu waktu natural menjadi khas perempuan dan membentuk sejarah yang subyektif. Kristeva menyontohkan waktu natural berhubungan dengan aktivitas atau tuntutan perempuan seperti halnya haid, mengasuh anak, perkawinan dan segala hal yang berkaitan dengan apa yang ada dalam diri perempuan dan tidak dialami oleh laki-laki. Waktu natural ini menjadikan perempuan terlihat istimewa sekaligus penyebab keterbatasan ruang gerak perempuan, waktu natural yang dimiliki perempuan ini tidak dapat dihindari 
akan tetapi tidak seharusnya menghalangi akan perjalan sejarah perempuan dalam historiografi.

Sumber sejarah yang bisa mengungkapkan tentang peran perempuan Indonesia pada masa lalu, adalah historiografi tradisional, itu pun hanya menyangkut perempuan kalangan elite dan sebagai tulisan yang bersifat androsentris, historiografi tradisional itu pun hanya sedikit saja menyinggung tentang kaum perempuan. Apa boleh buat, mari kita lihat bagaimana perempuan Indonesia digambarkan dalam historiografi tradisional. Historiografi tradisional adalah tulisan sejarah yang dibuat berdasarkan tradisi yang sudah berlangsung selama berabad-abad (masa klasik) dan ditulis oleh para pujangga, para empu, atau penulis-penulis khusus yang ada di istanaistana atau pendopo-pendopo kabupaten.

Historiografi tradisional ini dikenal dengan sebutan wawacan, babad, sejarah, serat, lontarak, hikayat, tambo, dan banyak lagi sebutan lainnya. Historiografi tradisional dapat dibedakan dengan historiografi modern karena dalam historiografi tradisional, selain fakta sejarah, juga dimuat unsur-unsur sastra dan mitos. Seringkali kebenaran historis tidak dibedakan dari kebenaran mitos, (Ricklefs, 2005, hal. 35) akan tetapi keabsahan historiografi tradisional ini perlu ditinjau ulang, mengingat sejarah adalah fakta masa lalu yang mempunyai unsur data dan dapat dipertanggung jawabkan akan kebenarannya.

Meskipun demikian, historiografi tradisional sangat penting artinya bagi sejarah karena di dalamnya terkandung nilai-nilai budaya masyarakat yang menghasilkan karya tersebut. Oleh karena itu, dari historiografi tradisional yang banyak memuat aspek non-historis sekalipun, kita dapat menangkap bagaimana citra perempuan Indonesia dalam sejarah masa lalu.

Menulis sejarah perempuan bukan tanpa kritik dari perempuan itu sendiri. Kritik yang cukup keras berasal dari kalangan genre yang berpandangan bahwa menulis sejarah perempuan sebagaimana hal tersebut 
dapat melanggengkan kenaturalan perempuan. Tetapi dari sudut pandang genre perbedaan kenaturalan perempuan justru harus ditampilkan tanpa perlu dipertentangkan. Menulis sejarah perempuan adalah menulis tentang diri perempuan sebagai spatio-temporal, konsep tentang diri yang memiliki dimensi waktu, ruang dan kesadaran.

Salah satu penulisan tentang perempuan yang mirip degan sejarah adalah penulisan yang tentang cerita dewi-dewi atas manusia dan alam seperti sungai, hutan, pertanian, kecantikan, kebijakan, dan sebagainya. Kejadian ini terjadi jauh sebelum abad pertegahan, semua itu menyiratkan adanya kekuasaan perempuan dalam hal kejadian penciptaan atau sebagai sumber yang mengawali terjadinya eksistensi kehidupan di bumi. Salah satu contoh adalah cerita tentang Dewi Nawang wulan, bidadari yang dikawini oleh Joko Tarub yang menanak nasi sebulir padi menjadi sekulai nasi dan cerita di daerah lain yang pemerannya perempuan sebagai objek utama cerita.

Penulisan cerita perempuan tersebut merupakan bagian "sejarah tentang perempuan". Akan tetapi dalam realitasnya belum ada pengakuan bahwa cerita tersebut adalah sejarah, karena adanya perdebatan mengenai mitos dan legenda rakyat yang disampaikan secara lisan belum bisa dijadikan sumber sejarah yang sahih. Sejarawan Indonesia memandang cerita tersebut tidak memilki dimensi politik, irasional dan sulit dipertanggung jawabkan secara metodologi sejarah.

Banyak persoalan yang akan dihadapi dalam menulis sejarah perempuan, namun menurut Vicky Bertram, metode otobiografis merupakan suatu jalan untuk mempertahankan kombinasi antara klaim pengetahuan subyektif dan obyektif secara teliti. (Bertram, 2009, hal. 56) Beliau berpendapat menulis sejarah perempuan merupakan kebutuhan untuk menggoreskan dan melibatkan perempuan dalam sejarah khususnya dalam tubuh politik. Karena sejarah perempuan ini belum memperoleh pengakuan dalam arus besar historiografi di Indonesia apa lagi di dunia. Salah satunya 
jalan yang tepat untuk melakukan hal itu adalah dengan membaca ulang teks sejarah dan pemikiran di masa lalu dan mengkritisinya, mendukung kepenulisan sejarah perempuan tidak hanya berkaitan tentang dunia politik atau perempuan-perempuan dari kalangan elit atau orang-orang besar saja, tapi juga dari perempuan-perempuan dari kalangan bawah dan yang paling terpenting adalah adanya minat yang tinggi untuk menulis sejarah perempuan oleh perempuan itu sendiri.

\section{PEREMPUAN DALAM SEJARAH ISLAM}

Sepanjang sejarah, isu-isu seputar perempuan berulang kali dibicarakan, baik oleh kalangan pemikir sekuler maupun agamawan. Pada periode Islam, abad pertengahan, dan era modern, semuanya menghasilkan teori dan ide-ide yang berbeda terhadap perempuan. Plato mengatakan, perempuan tercipta karena degenerasi manusia hanya pria yang diciptakan langsung oleh Tuhan dan diberi jiwa. Sedangkan Aristoteles memandang perempuan sebagai manusia "yang tidak sempurna", perempuan adalah "pria yang tidak produktif', karena lemah dalam hasrat, tidak mampu memasak cairan menstruasinya menjadi sesuatu yang lebih canggih, yang akan menjadi benih. Kontribusi perempuan pada embrio hanyalah substansi embrio itu dan sebuah wadah tempat embrio tumbuh.

Secara umum, hak-hak perempuan dianggap telah mendapat signifikansi yang kuat di masa modern, dan khususnya di dunia Islam. Namun, secara historis perempun masih juga tetap tersubordinasi oleh lakilaki. Perempuan dianggaap sebagai jenis kelamin kedua, (Engineer, 2005, hal. 1) sebagaimana Simon de Beavoir menggambarkan perempuan. Perempuan tak lebih dari sekedar makhluk yang di desain sewenang-wenang oleh kata perempuan. Perempuan adalah makhluk dengan sifat khususnya yang kurang berkualitas. (Behavior, 1999, hal. vi)

Teks-teks agama lebih jauh telah memanaskan konflik klasik tersebut karena telah disalah gunakan untuk menjustifikasi teori-teori androsentris. 
Sebagaimana yang kita lihat, peranan perempuan ditentukan oleh adat istiadat, gaya hidup, dan minimnya keterlibatan mereka dalam pemerintahan. Islam pada hakikatnya memiliki posisi yang tinggi di mata Tuhan, akan tetapi kebudayaanlah yang mengubah paradigma seperti ini..

Buku yang berjudul Analisis Gender dan Transformasi Sosial yang telah ditulis oleh Mandour Fakih telah menegaskan bahwa telah banyak kerancuan yang terjadi bahkan pemutar balikan makna yang dipahami oleh masyarakat terkait perbedaan seks dan gender. Karena fakta di masyarakat justru menganggap posisi perempuan dalam konstruksi sosial sebagai kodrat perempuan secara biologis. Oleh karena itu kemudian sering disebut sebagai "kodrat wanita" adalah konstruksi sosial dan kultural atau gender. (Fakih, 1996, hal. 11) Tatanan interaksi sosial dalam masyarakat dan budaya yang telah ada punya pengaruh besar dalam perkembangan gender.

Scott menegasikan bahwa sebenarnya istilah gender adalah pengganti bagi kata wanita yang mengandung pengertian hubungan sosial antara pria dan wanita. Artinya informasi tentang wanita dengan sendirinya berarti juga informasi tentang laki-laki. Dengan demikian istilah gender sebenarnya satu pengertian yang terpisah dari feminism dan tidak mengandung pernyataan tentang ketidaksetaraan dan kekuasaan. (Scott, Gender and the Politics oh History, 1988, hal. 31)

Bangsa-bangsa beradab meyakini bahwa perempuan merupakan manusia lemah, tak mampu menjaga dirinya sendiri secara independen, dan tak dapat dipercaya dalam segala urusan. (Thabathaba'i, hal. 62) Seperti pernah disampaikan Murtadha Muthahhari ketika melakukan analisis terhadap faktor-faktor sejarah, bahwa seseorang tak dapat mengingkari fakta bahwa pria telah berlaku kejam pada perempuan. Sepanjang sejarah, pria telah menindas perempuan akar penindasan jenis ini adalah bahwa terdapat banyak faktor, diantara faktor utamanya adalah kebodohan, bias, tradisi dan kebiasaan. 
Pandangan dunia dan ideologi manusia berkaitan erat dengan pandangan dunia dan ideologi yang disodorkan oleh agama yang dipeluknya. Dalam berbagai hakikat wujud dan substansi yang dimilikinya, pemeluk suatu agama mempunyai perspektif terhadap agama berupa serapan apa yang dipahami dari bacaan atau yang didengar. Al-Qur'an berbicara tentang kemanusiaan dalam cara yang sedemikian rupa guna mengingatkan bahwa kita diciptakan dari jenis yang sama, yang diidentifikasikan sebagai "diri yang satu".

Diri yang satu ini merefleksikan teori Islam bahwa pada periode primordial, hanya terdapat dua manusia Adam dan Hawa. Namun, apakah mereka diciptakan dalam kedudukan yang dibedakan berdasarkan gender, tentunya layak dipertanyakan. Banyak Muslim telah termanipulasi riwayatriwayat yang tidak otentik atau salah memahami teks-teks agama sedemikian rupa sehingga menciptakan jenis mentalitas primitif yang juga dijumpai di Eropa abad pertengahan. Jiwa-jiwa yang salah telah merepresentasikan citra yang terdistorsi sebagai deskriptifitas Islam yang sebenarnya. Disebabkan citra perempuan dalam Islam telah didistorsi dunia media massa yang manipulatif, perlu untuk menampilkan sebuah gerakan intelektual yang seimbang. Guna menampilkan pandangan Islam yang genuine seputar isu-isu gender dan respon Islam atas tuduhan-tuduhan yang tak berdasar.

Islam adalah agama yang berpijak pada prestasi, dengan demikian alQur'an menuntut umat untuk mengikuti jalan spritual yang berdasarkan atas peneladanan individu-individu yang paling dicintai Allah. Untuk membuat hal tersebut mungkin, al-Qur'an menampilkan semacam biografi spiritual kecil dari beberapa Nabi, syahid, dan orang-orang bijak. Sebagian besar teladan yang disajikan adalah pria. Namun disisi lain banyak deskripsi terperinci mengenai perempuan-perempuan sempurna dan agung yang disampaikan alQur'an. Yang paling masyhur diantaranya adalah Maryam, ibu Nabi Isa as 
dan banyak lagi sosok lain yang disajikan dalam buku-buku sejarah dan riwayat-riwayat Islam.

Perempuan-perempuan yang dipuji dalam sejarah dan riwayat-riwayat Islam ini menjadi penting karena al-Qur'an berbicara tentang perempuanperempuan yang hidup dimasa Rasulullah saw, membuktikan bahwa sepanjang sejarah kaum perempuan telah memperoleh status terhormat dalam Islam. (Hakeem, 2005) Al-Qur'an pada hakikat nya dalam sejarah Islam telah menggambarkan bahwa tidak ada perbedaan besar antara perempuan dan laki-laki. Semua makhluk hidup terutama manusia, perempuan ataupun laki-laki itu setara di mata Tuhan. Fitrahnya manusia mampu mencapai puncak spiritual yang puncaknya adalah untuk mendekatkan diri kepada Tuhan.

Leteratur Eropa abad pertengahan secara umum menggambarkan bagaimana perempuan dipandang sebagai warga negara kelas dua (second class citizens). Namun sumber-sumber sejarah abad pertengahan juga menyatakan bahwa intelektual-intelektual perempuan memberikan kontribusi yang cukup besar terhadap peradaban dan memperkaya khazanah intelektual.

Islam melalui nilai-nilai yang terkandung di dalamnya telah menempatkan perempuan sesuai dengan nilai kemanusiaannya. Karena seperti yang diketahui bahwa terdapat rentang waktu yang panjang antara Islam yang pertama kali muncul dengan Islam yang kita pahami saat ini. Proses yang panjang itu mungkin saja telah mengubah hakikat keislaman yang dipengaruhi oleh sosial masyarakat, kebudayaan ataupun teologi yang berbeda-beda.

\section{PEREMPUAN-PEREMPUAN YANG BERPENGARUH DALAM}

\section{SEJARAH}

Banyak studi yang telah memaparkan sosok perempuan baik dari segi medis, transmisi hadis, hukum, sastra dan pendidikan. Bahkan kemudian telah banyak kajian-kajian yang melibatkan kaum perempuan dalam 
pengembangan ilmu pengetahuan, teknologi ataupun pengobatan dalam sejarah tradisi keislaman.

Terkait contoh perempuan di atas, terdapat akademisi yang cukup memiliki peran dalam memajukan ilmu pengetahuan, mendirikan lembaga agama dan pendidikan serta lembaga amal. Misalnya Zubayda binti Ja'far alMansur sebagai seorang pelopor yang berupaya mensukseskan proyek pembangunan sumur layanan di sepanjang jalan ziarah Baghdad ke Makkah, contoh lain yakni Sutayta di mana ia merupakan tokoh yang ahli dalam bidang matematika dan juga merupakan saksi ahli di pengadilan, Ataupun tokoh perempuan Fatima al-Fehri yang telah mendirikan sebuah masjid yang bernama Qarawiyin di daerah Fez, Maroko, yang terkenal dengan unuversitas pertama di dunia, dan insinyur Al-'Ijlia yang membuat astrolab di Aleppo.

Selama beribu tahun yang lalu telah banyak simbol atau tanda yang telah ditinggalkan oleh sosok perempuan dalam masyarakat. Sejak zaman dahulu, Perempuan telah dikenal unggul dalam bidang puisi, sastra, kedokteran, matematika dan dilsafat. Sebagai contoh dalam hal ini adalah Hypatia (kira-kira pada 370-415 M), yakni seorang filsuf, astronom dan seorang guru di Kota Alexandria, Mesir.

Pada awal-awal kemunculan Islam. Perempuan telah banyak dibicarakan di dalam riwayat-riwayat. Perempuan juga banyak tergambar dalam proses perkembangan dan kemajuan Islam awal. Sebagai contoh yaitu 'Aisyah bint Abu Bakr, yang merupakan istri Nabi Muhammad saw yang paham dan mengerti tentang administrasi. Dia dikenal sebagai seorang yang aktif dalam dunia pendidikan dan orator, ia juga paham hadis, fikh dan ajaran Islam. Beberapa di antara perempuan itu dalam berbagai sumber juga banyak yang telah unggul dalam bidang-bidang lain, yakni sastra dan kedokteran, meskipun nama-nama mereka tidak terlalu populer. Pada masa yang lebih modern juga dikenal sosok Sabiha Gökçen (1913-2001M) yang merupakan 
sosok yang memperkenalkan gaya peperangan ala perempuan. Dia telah dijadikan sebagai kepala pelatih di Lembaga Aviasi Turki. (Gökçen, 2000)

Di indonesia juga tidak berbeda jauh dari perempuan lain di dunia. Banyak di antara tokoh perempuan Indonesia yang terkenal sebagai tokoh pejuang di bidang militer. Misalnya tokoh Tjut Mutia, Tjut Nyak Dien, Chirtina Martha Tiahahu dan Nyi Ageng Serang. Mereka ditangkap dan dipenjara seumur hidup, namun dikemudian hari banyak diperbincangkan dan menjadi perhatian penulis sejarah Belanda. Selain itu banyak penulis belanda juga memiliki ketertarikan kepada perempuan yang pemikiran dan kegiatan mereka ingin mengangkat derajat bangsa indonesia melalui pendidikan modern. Para perempuan perintis dan penyelenggara pendidikan ini bisa dilihat dari sosok Dewi Sartika, Kartini, Rahmah Elyunusia, Maria Walandau Maramis, Nyi Hadjar Dewantoro dan masih banyak perempuan lainnya yang memberikan kontribusi mereka terhadap perkembangan dalam perjalanan Indonesia yang tak kalah penting dari perjuangan laki-laki.

\section{PEREMPUAN DAN LAKI-LAKI}

Sepanjang sejarah manusia, perempuan banyak mengalami bentuk kedzaliman, seperti laki-laki juga mengalami hal yang sama dalam beberapa masa sejarah manusia. Kondisi perempuan yang lebih lemah dari sisi psikologi selalu menjadi kambing hitam, bahkan oleh orang yang paling dekatpun seperti ayah dan suami, meskipun dalam rentang waktu yang berbeda-beda. Bahkan Negara, organisasi dan perangkat hukum modern sekalipun dalam hal mengatur hubungan perempuan dan laki-laki selalu menempatkan perempuan dibawah laki-laki, baik dalam hal kedudukan maupun penghargaan.

Perempuan pada akhirnya berada dalam posisi sebagai bagian yang memodifikasi dari dominasi laki-laki. Relasi antara perempuan dan laki-laki tampak sebagai sebuah relasi yang tidak adil, korup, manipulatif, dan bersifat garis vertikal. Pengandaiannya seperti majikan dan bawahan. Kondisi 
perempuan klasik yang menyedihkan banyak terjadi dengan semena-mena. (Amin, 2003, hal. 29)

Sampai saat ini dalam kehidupan masyarakat masih terjadi perdebatan tentang teori nature dan teori nurture. Dalam kaitannya dengan jenis kelamin (seks), pengikut dua teori ini seperti air dengan minyak. Pengikut teori nature, secara ekstrem beranggapan bahwa perbedaan biologis antara perempuan dan laki-laki disebabkan oleh kontruksi sosial melalui sosialisaasi.

Perempuan sebagai manusia, seperti hal nya laki-laki juga belajar tentang kehidupan melalui pengalaman hidupnya. Tetapi, kenyataan biologis telah membedakan pengalaman hidupnya. Pengalaman hamil, melahirkan, dan menyusui memberikan pelajaran bagi perempuan bagaimana memelihara kehidupan, baik bagi dia sendiri maupun anak-anak yang dilahirkannya. Secara alamiah, perempuan berusaha memelihara kehidupan dengan belajar dari pengalamannya sendiri dan pengalaman kaumnya.

Dan ketika pesan-pesan agama samawi turun, banyak terjadi penyimpangan dan ketidak adilan dalam hak perempuan dari waktu kewaktu. Kemudian datanglah ajakan Islam untuk mengatur hubungan sosial antara laki-laki dan perempuan, dan menjadikan keduanya partner dalam memakmurkan bumi. ('Atif, 2016, hal. 50)

Kedudukan perempuan sebagai partner laki-laki dalam memakmurkan bumi ini seperti yang telah ditegaskan oleh Allah swt melalui kitab-Nya kepada perempuan dengan memberikan beban kepada perempuan seperti halnya Allah memberikan beban kepada laki-laki. Perempuan pun memperoleh ganjaran dan pahala atas ketaatan dalam menjalankan perintah Allah, sama seperti halnya ia memperoleh siksa jika berbuat maksiat.

'Dan janganlah kamu iri hati terhadap apa yang dikaruniakan Allah kepada sebahagian kamu lebih banyak dari sebahagian yang lain. (karena) bagi orang laki-laki ada bahagian dari pada apa yang mereka usahakan, dan bagi Para wanita (pun) ada bahagian dari apa yang mereka usahakan, dan mohonlah kepada Allah sebagian dari karunia- 
Nya. Sesungguhnya Allah Maha mengetahui segala sesuatu.” (Q. S. AlNisaa: 32)

Ayat dalam surah an-Nisaa di atas menjelaskan bahwa laki-laki dan perempuan masing-masing memiliki bagian dari apa yang mereka perbuat. Laki-laki diberikan kelebihan atas perempuan dalam masalah beban dan tanggung jawab, dan perempuan diberikan kelebihan atas laki-laki dalam masalah tugas dan pekerjaan. Keduanya melakukan tugas dan tanggung jawab sesuai dengan tabiatnya masing-masing dari segi struktur fisik dan kejiwaan.

Ketika laki-laki dan perempuan meyakini bahwa perbedaan keduanya adalah dalam masalah tugas (fungsi) bukan dalam masalah kemulian status ataupun derajat dan ketika seorang perempuan yakin bahwa syariat Islam memuliakannya baik sebagai seorang anak, ibu maupun istri dengan syari'at Islam ia bisa mencapai puncak yang tidak bisa dicapai laki-laki, maka semua akan tahu bahwa kedudukan perempuan dalam agama Islam tidak ada yang menandingi. Dalam pandangan Islam ia adalah manusia yang utuh sebelum ia menjadi seorang perempuan.

Teori feminisme eksistensialis menganalisis sejarah manusia dari data biologisnya. Setelah lepas dari tubuh dan berada di luarnya, sperma telah menjadi objek bagi laki-laki. Berbeda dengan telur yang lepas dari ovum, ia tetap bersama perempuan dan tumbuh sebagai kehidupan baru. Tetapi faktanya bahwa perempuan teraliensi dan dianggap sebagai objek, pada dasarnya biologis inilah yang mendasari teori ini, agar perempuan menyadari keberadaan dirinya, terkhusus bagi mereka yang sudah mengalami melahirkan. (Murnia, 2004, hal. 132) Sedangkan gagasan teori feminisme secara umum adalah kenyataan teori yang muncul berdasarkan dari kesadaran bahwa adanya penyimpangan dalam sejarah dan keyakinan akan posisi kaum wanita selama ini.

Kesadaran perempuan tentang eksistensi dirinya ini, tertutup oleh mitos tentang perempuan yang sengaja diciptakan. Misalnya mitos tentang 
tulang rusuk, sperma bersifat agresif dan telur bersifat pasif, tugas reproduksi membuat tubuh menjadi lemah dan sebagainya. Dengan kesadaran ini, kaum perempuan dapat mengendalikannya supaya tidak dikendalikan laki-laki. Lakilaki dan perempuan kembali bersama-sama menyatukan pandangan mereka yang berbeda untuk melakukan kegiatan yang mengatur segala aspek kehidupan tanpa dikotomi kuat dan lemah.

Dalam sejarah pergerakan perempuan menunjukkan bahwa perempuan Indonesia telah membuktikan perjuangannya. Pada waktu perang misalnya, perempuan diberi hak dan kewajiban yang sama untuk berjuang melawan penjajah. Perempuan muncul melalui gerakan-gerakan organisasinya yang independen, muncul sebagai pribadi dan bukan dalam kedudukan mereka sebagai seorang istri.

Akar teori antara perempuan dan laki-laki bertumpu pada kebebasan dan kesetaraan rasionalitas. Perempuan adalah makhluk rasional, kemampuannya sama dengan laki-laki, maka dari itu perempuan dan laki punya hubungan yang erat dalam hal apa pun karena laki-laki dan perempuan adalah manusia yang saling membutuhkan.

\section{KESIMPULAN}

Pada hakikatnya perempuan punya nilai tersendiri dalam sejarah historiografi dan sejarah Islam, namun hal itu tak tampak dalam penulisan sejarah baik itu dalam sejarah dunia maupun di Indonesia. Disebabkan stigma tentang perempuan sebagai manusia kelas dua yang ditanamkan sejak berabad-abad lalu cukup mengakar itulah sebabnya mengapa perempuan tersembunyi dalam sejrah, butuh waktu dan perjuangan yang panjang untuk mengubah dan mengatasi hal tersebut.

Padahal jika kita telaah lebih dalam, perempuan dalam sejarah historiografi dan sejarah Islam banyak berkontribusi sejalan dengan perkembangan sejarah hingga saat ini. Gender dan feminisme adalah salah 
satu topik dan salah satu usaha yang marak dan terus dicanangkan untuk mengubah cara pandang terhadap perempuan.

\section{DAFTAR PUSTAKA}

'Atif, U. A. (2016). Menjadi Muslimah Idaman. Jakarta: Mirqat.

Amin, Q. (2003). Sejarah Penindasan Perempuan: Menggugat "Islam laki-laki" menggugat "Perempuan Baru”. (S. Alam, Trans.) Yogyakarta: IRC.

Behavior, S. d. (1999). Pengantar” Second Sex, Fakta dan Mitos. (T. B. Febriyantono, Trans.) Surabaya: Pustaka Promethea.

Bertram, V. (2009). Menteorikan yang Personal: Penggunaan Autobiografi dalam Tulisan akademis. In Teori-Teori Feminis Kontemporer (p. 56). Bandung: Jalasutra.

Carroll, B. A. (n.d.). Liberating Women's History. Urbana Champaign, $75-76$.

Engineer, A. A. (2005). Pembebasan Perempuan. Jakarta: LkiS.

Fakih, M. (1996). Analisis Gender \& Transformasi Sosial. Yogyakarta: Pustaka Pelajar.

Gökçen, S. (2000). Atatürk'le Bir Ömür (A Life with Atatürk) (in Turkish). Istanbul: Altin Kitaplar.

Hakeem, A. H. (2005). Membela Perempuan, Menakar Feminisme dengan Nalar Agama. Jakarta: Al-Huda.

Kowani. (1984). Sejarah Setengah Abad Pergerakan Perempuan Indonesia. Jakarta: Balai Pustaka.

Kuntowijoyo. (1994). Metodologi Sejarah. Yogyakarta: Universitas Gajah Mada.

Murnia, A. (2004). Getar Gender. Magelang: KDT.

Purwanto, B. (2006). Gagalnya Histriografi Indonesiasentris. Yogyakarta: Ombak. 
Ricklefs, M. (2005). Sejarah Indonesia Modern: 1200-2004. (S. W. dkk, Trans.) Jakarta: Serambi.

S. Handayani, C. (2004). Kuasa Perempuan Jawa. Yogyakarta: LKiS.

S.Duval. (1998). New Veils and New Voices: Islamist Women's Group in Egypt. In Women and Islamization: Contemporary Dimensions of Discourse on Gender Relations (p. 46). Berg: Oxford and New York.

Scott, J. W. (1988). Gender and the Politics of History. USA: Columbia University Press.

Scott, J. W. (1988). Gender and the Politics oh History. New York: Columbia University Press.

Thabathaba'i, M. H. (n.d.). An Exegesis of the of the al-Qur'an (Vol. 4). (S. Razawi, Trans.) 